\title{
Patchiness of macrobenthic invertebrates in homogenized intertidal habitats: hidden spatial structure at a landscape scale
}

\author{
Casper Kraan ${ }^{1, *}$, Jaap van der Meer ${ }^{1}$, Anne Dekinga ${ }^{1}$, Theunis Piersma ${ }^{1,2}$ \\ ${ }^{1}$ Department of Marine Ecology, Royal Netherlands Institute for Sea Research (NIOZ), PO Box 59, 1790 AB Den Burg, Texel, \\ The Netherlands \\ ${ }^{2}$ Animal Ecology Group, Centre for Ecological and Evolutionary Studies (CEES), University of Groningen, PO Box 14, \\ 9750 AA Haren, The Netherlands
}

\begin{abstract}
Many terrestrial habitats, and certainly man-made systems such as woodland and agricultural habitats, are characterised by a mosaic of different habitat types. In contrast, most seafloors have a rather uniform visual appearance which is enhanced by the cryptic nature of many of their inhabitants. The present study aimed to: (1) describe landscape scale spatial patterns of benthic infauna after evaluating 3 methods for analyzing autocorrelations (Moran's $I$, semivariance and fractals), (2) compare the benthic patterns with patterns described for other organisms, and (3) highlight shared characteristics. During 4 consecutive years (2002 to 2005) we assessed spatial structuring of 4 intertidal benthic invertebrates (Cerastoderma edule, Macoma balthica, Nereis diversicolor and Nepthys hombergii) in the Wadden Sea, The Netherlands. We annually sampled $\sim 2750$ stations based on a $250 \mathrm{~m}$ grid, covering an area of ca. $225 \mathrm{~km}^{2}$. On the basis of simulated spatial distributions, we selected Moran's I to analyze spatial patterns for the following reasons: (1) due to standardization, results can be directly compared, (2) Moran's I is the least difficult to evaluate, since it is related to the familiar Pearson's correlation coefficient, and (3) significance can readily be assessed. The 4 benthic species were all spatially structured at the landscape scale, with spatial features being smaller than the physical structure of the intertidal environment, i.e. the intertidal extent. During the $4 \mathrm{yr}_{\text {, some }}$ species changed their distribution, but spatial characteristics, i.e. patch size and amplitude of autocorrelation, remained similar. Higher overall density resulted in stronger autocorrelation with no differences between species. A comparison between spatial structuring of benthic fauna with patterns encountered in other habitats, whether marine or terrestrial, was unsuccessful due to differences in extent and grain. We argue that future research should focus on spatial structure in species' distributions as an ecological relevant parameter.
\end{abstract}

KEY WORDS: Cryptic macrozoobenthos $\cdot$ Intertidal $\cdot$ Landscape scale $\cdot$ Patch size $\cdot$ Spatial structure $\cdot$ Wadden Sea Resale or republication not permitted without written consent of the publisher

\section{INTRODUCTION}

The ecological world is patterned and patchy (Sparrow 1999, Wiens 2000); however, there are large differences in the physical appearance of this environmental heterogeneity. For example, arable farmland, with intensively managed fields separated by semi-natural field margins, comprises a heterogeneous mosaic of habitat types (Stewart et al. 2000). Woodland, as de- picted in detail by Elton (1966), also is characterized by many different habitat types. Arguably, at the other end of the range are soft-sediment seafloors. They are fairly homogeneous and featureless, without sharp boundaries between habitat types, only limited in extent by the low-water mark (e.g. Verwey 1952, Peterson 1991). The animal assemblages of such flats are dominated by invertebrates that live hidden beneath the muddy or sandy surface (Peterson 1991, Thrush 
1991). Other features also separate coastal marine habitats from terrestrial habitats, amongst others the spatial scale of gene flow and the openness of communities (Carr et al. 2003).

An element that most habitats have in common is anthropogenic interference (associated with resource extraction, land use and development) as the dominant form of landscape disturbance. When these activities occur on a large scale they often tend to homogenize landscape patterns (Watling \& Norse 1998, Wiens 2000). For example, mussel beds (Mytilus edulis) provide some structural heterogeneity on intertidal mudflats in the Dutch Wadden Sea (Verwey 1952, Dankers \& Zuidema 1995). However, these beds were mechanically harvested between 1989 and 1991 (Piersma et al. 1993) and have not yet returned, which can be credited partially to another benthic fishery, i.e. cockle-dredging (Kraan et al. 2007).

The intertidal flats of the Wadden Sea are well studied with respect to species, numbers and biomass of macrobenthic fauna (Beukema et al. 1993, Piersma et al. 1993, Zwarts \& Wanink 1993, Flach 1996, Dekker \& Beukema 1999) and to a lesser extent with respect to the impacts of industrial harvesting of shellfish (but see Piersma et al. 2001, van Gils et al. 2006a, Kraan et al. 2007). However, a spatially explicit description of macrobenthic species' distributions, using tools from landscape ecology in an integrative and interdisciplinary approach (Wu \& Hobbs 2002), has not been conducted.

Based on a large-scale benthic research effort in the Dutch Wadden Sea (see Piersma et al. 2001, Kraan et al. 2007), we here describe spatial patterns of macrozoobenthic species in homogenized intertidal sandflats at an ecologically relevant landscape scale and describe shape and size of patches, as well as consistency of patches in time. Four abundant macrozoobenthic species, 2 bivalves (Macoma balthica and Cerastoderma edule) and 2 polychaete worms (Nereis diversicolor and Nephtys hombergii), were chosen to illustrate hidden spatial patterning within intertidal sands.

A literature survey, based on ecological studies that: (1) sample a grid, (2) apply one of 3 methods for spatial analysis tested below, and (3) do not use remote sensing or satellite data, indicates that our study effort belongs to the few that combine a large sampling area $\left(>1 \mathrm{~km}^{2}\right)$ with a large number of samples (>1000 samples) (Fig. 1, Table 1). Usually, spatial research is performed at either a large scale with few sampling stations (e.g. Morrisey et al. 1992, Thrush et al. 1994, Fauchald et al. 2002) or a small scale with close-range coring (e.g. Reise 1979, Hewitt et al. 1997b, Legendre et al. 1997).

To decide which of 3 different methods best describes spatial structures of benthic infauna, we simulated a range of distributions to create a spectrum of spatial

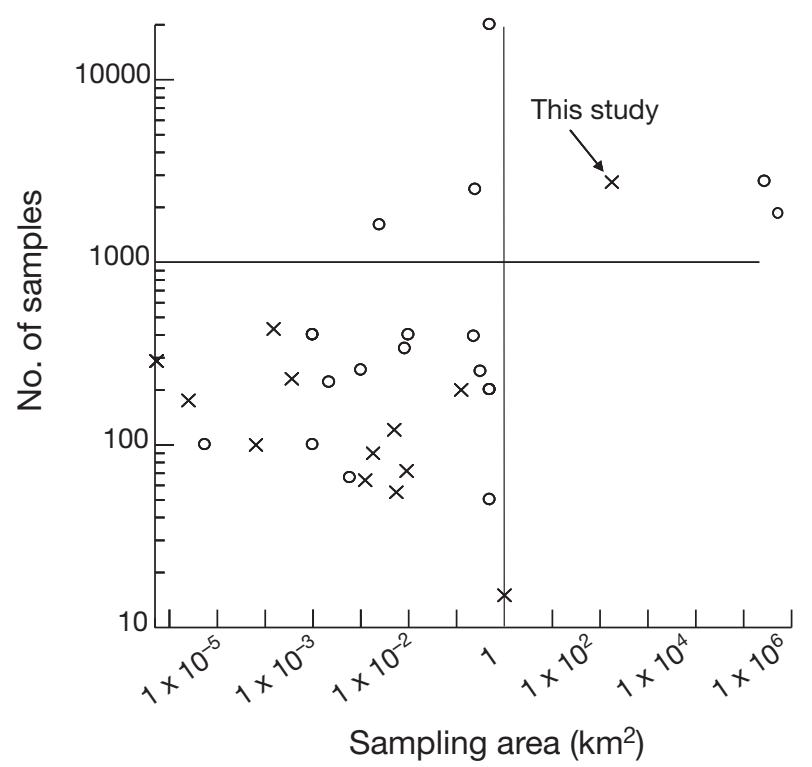

Fig. 1. Numbers of samples taken and the total area covered $\left(\mathrm{km}^{2}\right)$ in published spatial papers. ( $\left.\mathrm{\times}\right)$ : marine studies; (O): terrestrial. The vertical line denotes a sampling area of $1 \mathrm{~km}^{2}$, whereas the horizontal line divides studies with more than 1000 samples from studies with fewer samples

patterns. The simulated patterns were used to examine the behaviour of Moran's I (Moran 1950, Sokal \& Oden 1978, Cliff \& Ord 1981), semivariance (e.g. Rossi et al. 1992) and fractals (Burrough 1981, Palmer 1988), not only to develop a better understanding of the translation from process to pattern, but also to note possible differences between the methods applied. So far, Moran's $I$ has been scarcely used in marine ecological research (e.g. Volckaert 1987, Hewitt et al. 1997a,b, Legendre et al. 1997); the remaining two are popular in plant and landscape ecology (Rossi et al. 1992, He et al. 1994, Fortin \& Dale 2005).

\section{MATERIALS AND METHODS}

Study area. The surveyed intertidal areas in the western part of the Dutch Wadden Sea $\left(53^{\circ} \mathrm{N}, 4\right.$ to $\left.5^{\circ} \mathrm{E}\right)$ (Fig. 2) covered a surface of approximately $225 \mathrm{~km}^{2}$. The area mainly consists of gullies, intertidal and subtidal mudflats, and is bordered to the west and north by the barrier islands of Texel, Vlieland and Terschelling. The western Wadden Sea has a semi-diurnal tide and tidal amplitude varying between $1.5 \mathrm{~m}$ at neap tides to $2.5 \mathrm{~m}$ at spring tides. About three-quarters of this area consists of soft-sediment flats, exposed at low tides. The sediment composition of the intertidal flats can be characterized as sands and muddy sands, with median grain sizes ranging from 140 to $200 \mu \mathrm{m}$ (Piersma et al. 1993, Zwarts et al. 2003). 
Table 1. Literature overview, showing studies that based their spatial analysis on Moran's I, semivariance or fractals, sampled an evenly spaced grid and did not use remote sensing or satellite data

\begin{tabular}{|c|c|c|c|c|c|}
\hline Topic & Environment & Country & Site size $\left(\mathrm{km}^{2}\right)$ & Samples (n) & Source \\
\hline Macrozoobenthos & Marine & The Netherlands & $1.75 \times 10^{2}$ & 2750 & Present study \\
\hline Zoobenthos & Marine & Sweden & $1.50 \times 10^{-5}$ & 432 & Bergström et al. (2002) \\
\hline Meiofauna \& microalgae & Marine & USA & $5.42 \times 10^{-8}$ & 288 & Pinckney \& Sandulli (1990) \\
\hline Meiofauna \& microalgae & Marine & USA & $5.42 \times 10^{-8}$ & 288 & Sandulli \& Pinckney (1999) \\
\hline Bivalves & Marine & New Zealand & $3.60 \times 10^{-5}$ & 230 & Hewitt et al. (1996) \\
\hline Bivalves & Marine & New Zealand & $1.25 \times 10^{-1}$ & 200 & Legendre et al. (1997) \\
\hline Polychaetes & Marine & Canada & $2.50 \times 10^{-7}$ & 175 & Volckaert (1987) \\
\hline Ecklonia radiata & Marine & New Zealand & $5.00 \times 10^{-3}$ & 121 & Cole \& Syms (1999) \\
\hline Macrozoobenthos & Marine & USA & $6.45 \times 10^{-6}$ & 100 & Jumars et al. (1977) \\
\hline Chione stutchburyi & Marine & New Zealand & $1.80 \times 10^{-3}$ & 90 & McArdle \& Blackwell (1989) \\
\hline Macrozoobenthos & Marine & New Zealand & $9.00 \times 10^{-3}$ & 72 & Thrush et al. (1994) \\
\hline Bivalves & Marine & Scotland & $1.23 \times 10^{-3}$ & 64 & Huxam \& Richards (2003) \\
\hline Macrozoobenthos & Marine & New Zealand & $5.50 \times 10^{-3}$ & 55 & Hewitt et al. (1997b) \\
\hline Mactra ordinaria & Marine & New Zealand & $1.00 \times 10^{0}$ & 15 & Cole et al. (2001) \\
\hline Tree diversity & Other & Malaysia & $5.00 \times 10^{-1}$ & 20000 & He et al. (1994) \\
\hline Freshwater turtles & Other & Spain \& Portugal & $2.77 \times 10^{5}$ & 2772 & Segurado et al. (2006) \\
\hline Plants & Other & China & $2.50 \times 10^{-1}$ & 2500 & He et al. (2007) \\
\hline Bird diversity & Other & South Africa & $1.26 \times 10^{6}$ & 1858 & van Rensburg et al. (2002) \\
\hline Perennial vegetation & Other & Spain & $2.50 \times 10^{-3}$ & 1600 & Maestre et al. (2005) \\
\hline Ambrosia dumosa & Other & USA & $1.00 \times 10^{-2}$ & 400 & Perry et al. (2002) \\
\hline Soil seedbank & Other & Spain & $1.00 \times 10^{-4}$ & 400 & Reiné et al. (2006) \\
\hline Plant abundance & Other & Spain & $1.00 \times 10^{-4}$ & 400 & Reiné et al. (2006) \\
\hline Cattle & Other & Switzerland & $2.32 \times 10^{-1}$ & 393 & Kohler et al. (2006) \\
\hline Plant abundance & Other & USA & $8.40 \times 10^{-3}$ & 336 & Fortin (1999) \\
\hline Erythronium grandiflorum & Other & USA & $1.02 \times 10^{-3}$ & 256 & Thomson et al. (1996) \\
\hline Dyschirius globosus & Other & The Netherlands & $3.20 \times 10^{-1}$ & 252 & Rossi et al. (1992) \\
\hline Silene latifolia & Other & USA & $2.20 \times 10^{-4}$ & 220 & Real \& McElhany (1996) \\
\hline Acer saccharum & Other & Canada & $5.00 \times 10^{-1}$ & 200 & Fortin et al. (1989) \\
\hline Tsuga canadensis & Other & Canada & $5.00 \times 10^{-1}$ & 200 & Legendre \& Fortin (1989) \\
\hline Potamogeton pectinatus & Other & The Netherlands & $1.00 \times 10^{-4}$ & 100 & Klaassen et al. (2006) \\
\hline Balanus balanoidus & Other & The Netherlands & $5.63 \times 10^{-7}$ & 100 & Rossi et al. (1992) \\
\hline Liatris cylindracea & Other & USA & $5.94 \times 10^{-4}$ & 66 & Sokal \& Oden (1978) \\
\hline Macaranga lowii & Other & Malaysia & $5.00 \times 10^{-1}$ & 50 & Bellehumeur \& Legendre (1998) \\
\hline
\end{tabular}

Sampling. Benthic samples were collected in August and September 2002 to 2005 and were part of longterm benthic research efforts that began in 1988 (Piersma et al. 1993, 2001, van Gils et al. 2006a). Measured densities of benthic fauna do not demonstrably change over this 2 mo sampling period (Piersma et al. 1993). We collected samples over a predetermined $250 \mathrm{~m}$ grid that covered the intertidal mudflats (Fig. 2), using hand-held GPS (Garmin 12 and 45) to locate sampling sites. These sampling positions were assigned in the first year and revisited in the years after (van der Meer 1997). On average we sampled 2750 stations annually with maximum of 2784 stations in 2005 and a minimum of 2732 stations in 2002.

Some of the sampling stations were visited on foot during low tide, others by boat during incoming, high or outgoing tides. On foot, 1 sediment core of $0.018 \mathrm{~m}^{2}$ down to a depth of $20 \mathrm{~cm}$ was taken at each station. By boat, a total surface of $0.017 \mathrm{~m}^{2}$ divided over 2 cores, also to a depth of $20 \mathrm{~cm}$, was sampled at each station. Maximum water coverage to allow boat sampling was approximately $2 \mathrm{~m}$. A comparison between both sam- pling methods, based on neighbouring sampling stations, showed no differences (Kraan et al. 2007). After sieving over a $1 \mathrm{~mm}$ mesh, all fauna were counted and recorded. All crustaceans and molluscs were collected in plastic bags and stored at $-20^{\circ} \mathrm{C}$ for later analyses in the laboratory (for details see Piersma et al. 1993, van Gils et al. 2006a,b).

Simulations. Spatial structures were simulated using a $20 \times 20$ lattice with cell values ranging between 1 and 10 (see Fig. 3). Note that simulation entailed manually rearranging cell values to create the desired spatial structure. Structures varied from complete randomness, via a gradient, to different sized random patches, effectively covering the most extreme and instructive results of spatial partitioning (see Fig. 3). Geographical coordinates were assigned by using column and row number, respectively. All simulations were done in Excel, and spatial patterns were analyzed with GS+ (Robertson 2000).

Spatial analysis. To rule out the possibility that the patterns we describe are identical to the physical structure of intertidal mudflats, a grid with an equal 


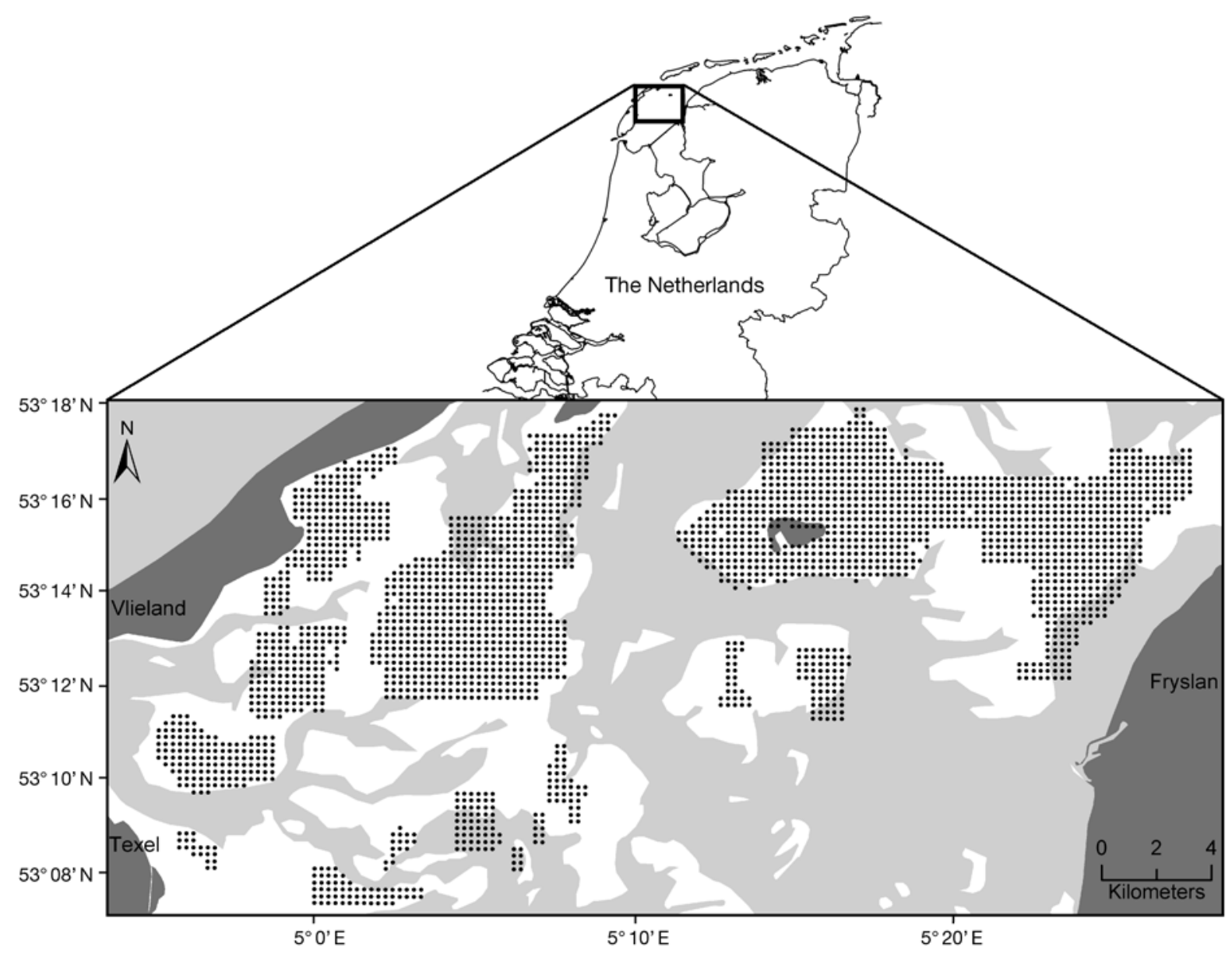

Fig. 2. Benthic sampling stations $(\bullet)$ on a $250 \mathrm{~m}$ grid in the western Dutch Wadden Sea. White areas indicate mudflats exposed during low low-water at spring tides, light grey areas indicate water and the dark grey area indicates land

extent (i.e. the total area covered) and grain (i.e. the sampling interval, e.g. Hewitt et al. 1998) as the research programme was created in a GIS environment. Stations that overlapped with sampled positions were given a value of 1 and stations outside the sampled positions were set at 0 , followed by an analysis of spatial patterns. This allowed a direct comparison between all-directional autocorrelation patterns of the benthic species - based on abundances at sampled stations only, and the physical environment-using the imposed grid. This background autocorrelation is presented as dashed lines in Figs. 4 to 7 .

Moran's I estimates the autocorrelation coefficient of a variable for all pairs of sampling stations at a given spatial interval (Cliff \& Ord 1981, Fortin \& Dale 2005). Like its close relative, the Pearson's product-moment correlation, Moran's I is sensitive to deviations from the mean and asymmetry in the distribution (Legendre \& Fortin 1989, Legendre \& Legendre 1998). These deviations may result in violation of stationarity, implying that the mean and variance are not stable across the extent studied. To stabilize the mean and variance as much as possible, prior to analysis all abundance data were $\log$-transformed, $\mathrm{x}^{\prime}=\log (\mathrm{x}+1)$ (Zar 1996). The null hypothesis of no autocorrelation was tested with a Monte Carlo procedure using 999 runs (see Manly 1997, Rangel et al. 2006). Patch sizes are normally set at the point where Moran's $I$ is no longer different from random (Sokal \& Oden 1978). In our case, however, due to the very large number of pairs in each lag, almost all values were statistically significantly different from random. To be able to assign meaningful patch sizes, we chose to set the threshold value of what we consider biologically meaningful at $I=0.1$, since all but the most extreme values occurred between -0.1 and 0.1 . To evaluate the robustness of this admittedly arbitrary choice, we also determined patch sizes using $I=0.08,0.12,0.14$ and 0.16 as threshold values. Exactly the same patterns were derived, since patch sizes just shifted some distance classes up or down. Generally, the shape of a correlogram is regarded as the key characteristic, since this is associated with a certain spatial structuring of the data (Legendre \& Fortin 1989).

Another way to capture spatial structure is to use semivariance, which is also calculated per distance class (Rossi et al. 1992). A plot of semivariance values 
against the spatial lags is called a (semi-)variogram. Spatial interpolation, e.g. kriging, uses the information captured by a variogram to interpolate a surface (e.g. van der Meer \& Leopold 1995). The derived parameters 'nugget', 'sill' and 'range' give information on variation captured by the model, unexplained variation and the range of autocorrelation, respectively (Bellehumeur \& Legendre 1998). Unlike Moran's I, semivariance is not standardized and is in the same units as the original data.

When plotting semivariances for the different distance intervals on a log-log scale, the slope can be used to calculate the fractal dimension (Burrough 1981). This is a mathematical coefficient that measures the fractal geometry (non-integer dimension) of objects in space. The double-log semi-variogram need not be linear and may display so-called spatial breaks with differing fractal dimensions (Johnson et al. 1995, Fortin $\&$ Dale 2005). Self-similarity thus occurs within a certain scale range, indicating that the fractal dimension is not necessarily a constant function of scale (Palmer 1988), and points at different levels of organization in space and a change in structuring ecological processes. Double-log variograms and fractals are illustrated by Burrough (1981), Palmer (1988) and Fortin \& Dale (2005). Analyses were done with GS+ (Robertson 2000) or SAM (Rangel et al. 2006).

\section{RESULTS}

\section{Simulations}

For a randomly distributed mosaic of differing values without clear patches (Fig. 3a), none of the 3 methods showed significant autocorrelation, indicating the absence of spatial structure. The double-log variogram (Fig. 3a) indicated that species distribution was a constant function of scale; it was completely self-similar. When values were structured along a gradient (Fig. 3b), short-distance positive autocorrelations typically were coupled with very negative autocorrelations at the largest distances in the correlogram. The strength of structuring processes gradually decreased with increasing distance, shown by points farther apart having very different abundances. The semivariogram, as well as the double-log variogram, showed increased semi-variance values with increased distance classes, the same as given by the correlogram.

Arrangements of values in a way that generated one large patch (Fig. 3c) gave significant positive autocorrelations at the shortest and longest intervals and negative values at intermediate distances in the correlogram. The patch size was approximately 7 units; this is the point where the correlogram crosses the 0-line. The variogram is a mirror image of the correlogram, with highest values at intermediate distances, showing the same spatial range. The double-log variogram contained no linear part; there were no spatial breaks or spatial ranges with a constant fractal dimension D.

Evenly spaced multiple small patches of equal size (Fig. 3d) were represented by a repetition of patterns in the correlogram, variogram and double-log variogram. The distance between the first peak and the first trough in the correlogram indicates the patch size ( 2.0 units), and the continuing oscillation with decreasing amplitude revealed a repetitive pattern of patches. The 2 other methods also gave the same repetitive pattern. The fractal dimension therefore was only constant until a distance of 2 units; the rest can be considered noise.

When repeating the same simulated patches as above, but now randomly distributed across the area (Fig. 3e), the only obvious pattern was that of positive autocorrelations over small distances in the correlogram, the maximum semivariance value already at a small spatial range in the variogram and the absence of a linear part in the double-log variogram. The repetition of patches, though of the same size as in the previous simulation, was not clearly captured by any of the methods.

Differently sized random patches (Fig. 3f) created a pattern that was characterized by strong shortdistance positive autocorrelations, followed by nonsignificant random variation with increasing distance. This variation is due to the differing patch sizes and differing inter-patch distances. Again there was no linear element in the double-log variogram.

The correlogram and the variogram showed similar spatial structuring on the basis of simulated distributions (Fig. 3a-f), but the correlogram was easier to understand, being so similar to the Pearson's productmoment correlation. The double-log variogram, used to determine the fractal dimension $\mathrm{D}$, added the least information to the outcome of the analyses. Due to the absence of a linear relationship between log-distance interval and log-semivariance, D often did not capture the spatial characteristics. Based on these results, we carried out the spatial analysis of census data with Moran's I only.

\section{Intertidal macrozoobenthos}

The intertidal mudflat habitat itself has a certain physical structure in space, and this spatial structure was shown with Moran's I values and presented in Figs. 4 to 7 for comparison with the spatial characteristics of the distribution of benthic species (see 'Materi- 
a) Random distribution

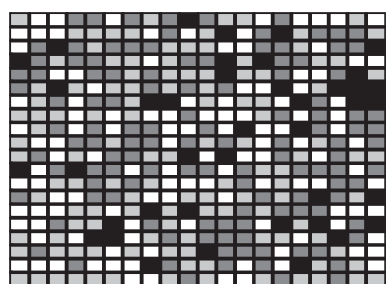

b) Gradient

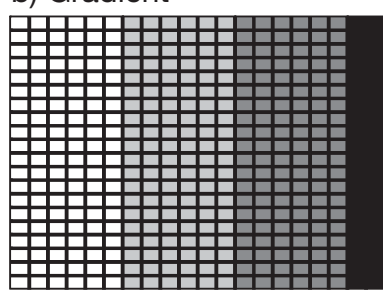

c) One large patch

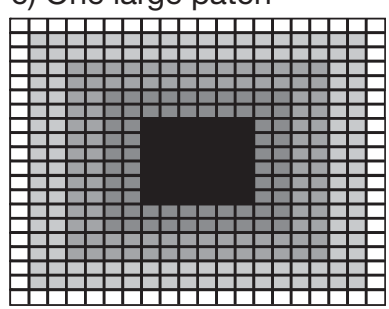

d) Multiple small patches
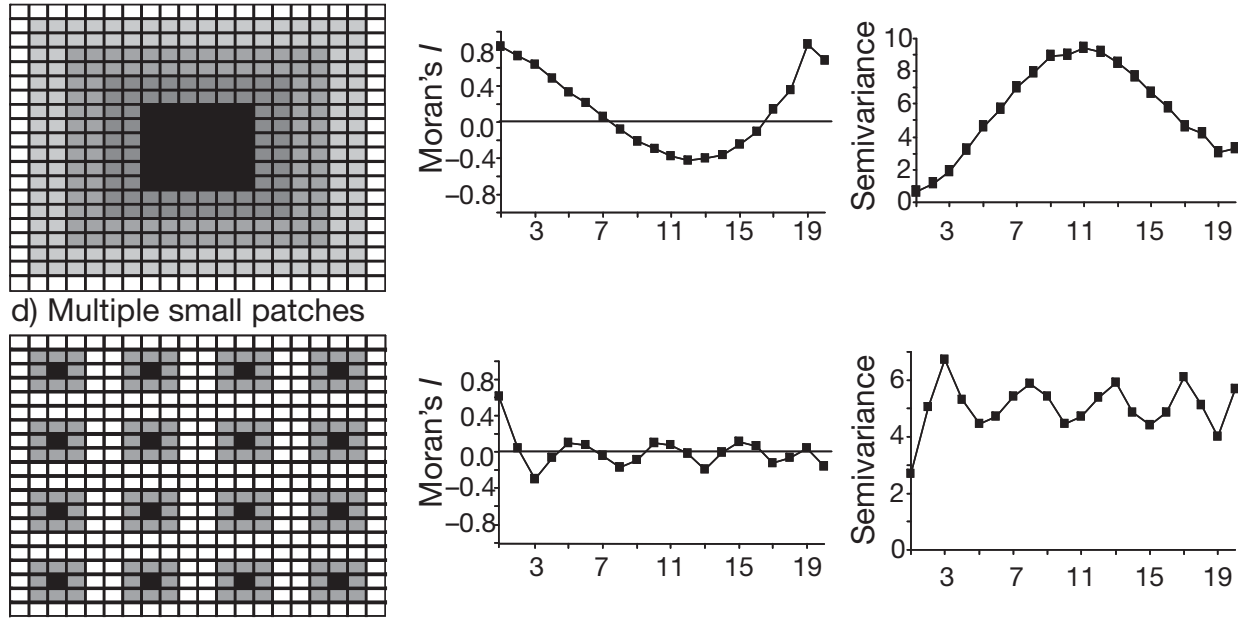

e) Multiple random small patches
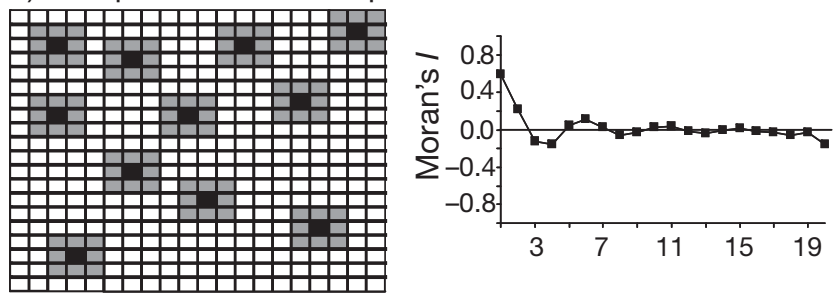

f) Multiple random patches
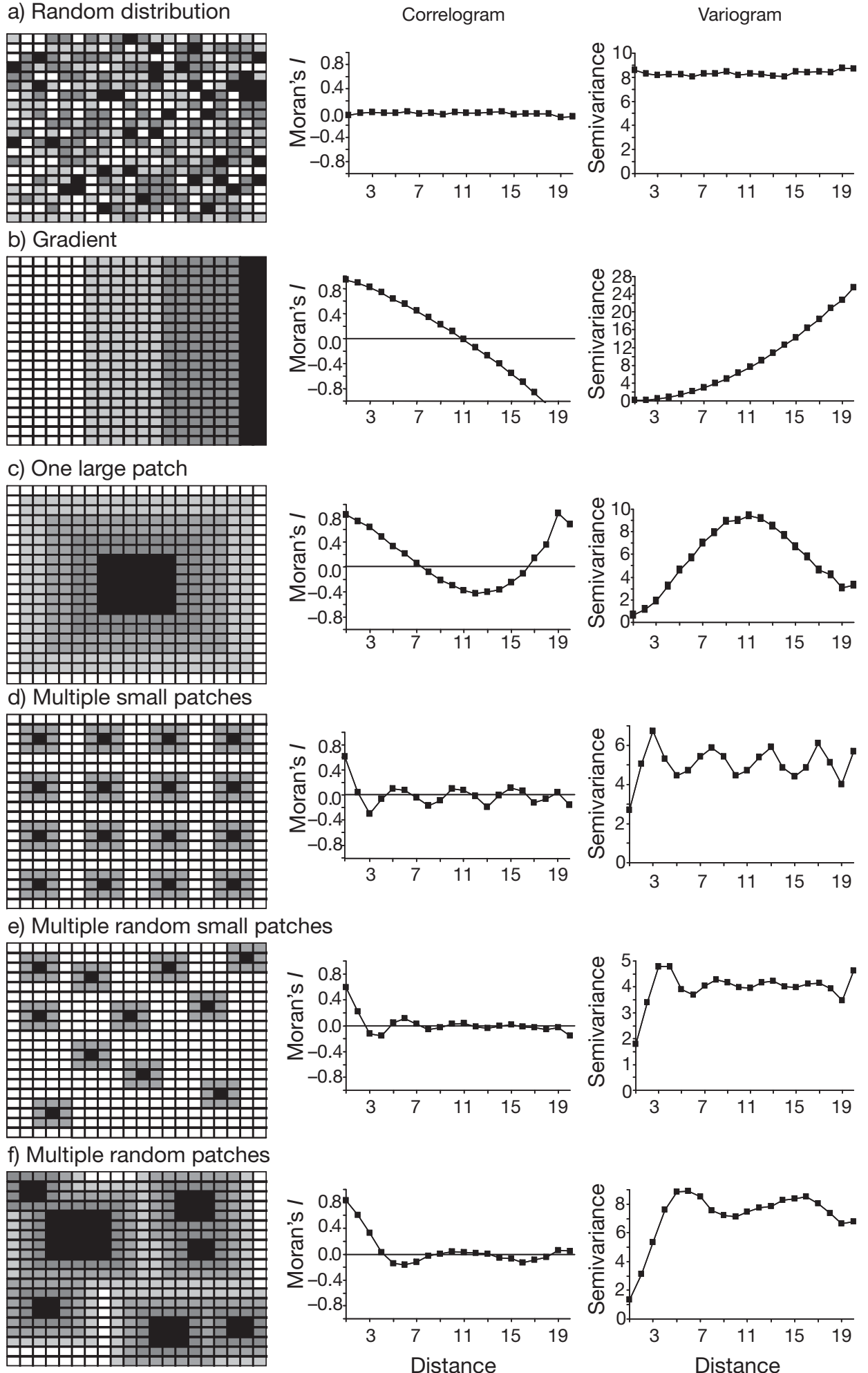
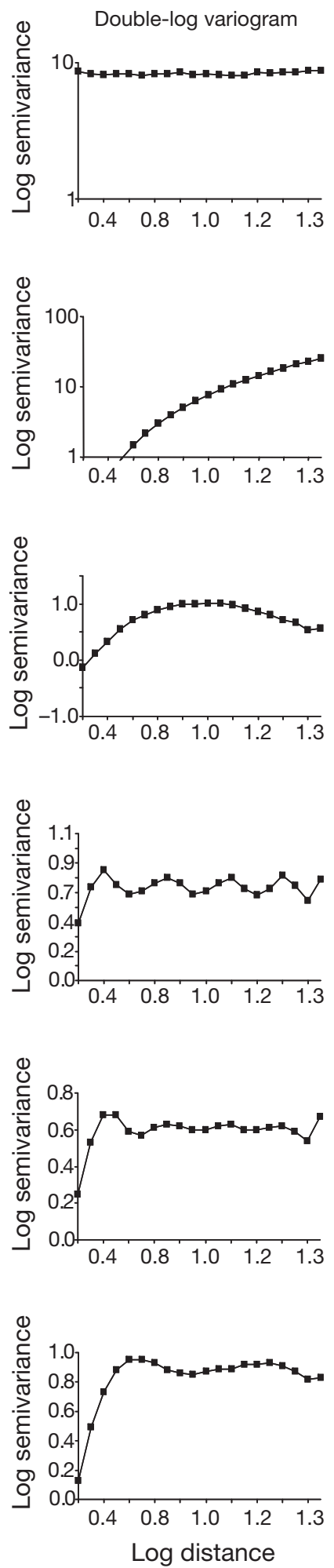

Fig. 3. Simulated spatial patterns where the value increases from 1 (white) to 10 (black), analyzed with Moran's $I$ (correlogram), semivariance (variogram) and fractal dimension (double-log variogram). The complexity of the simulated pattern increases from top to bottom 

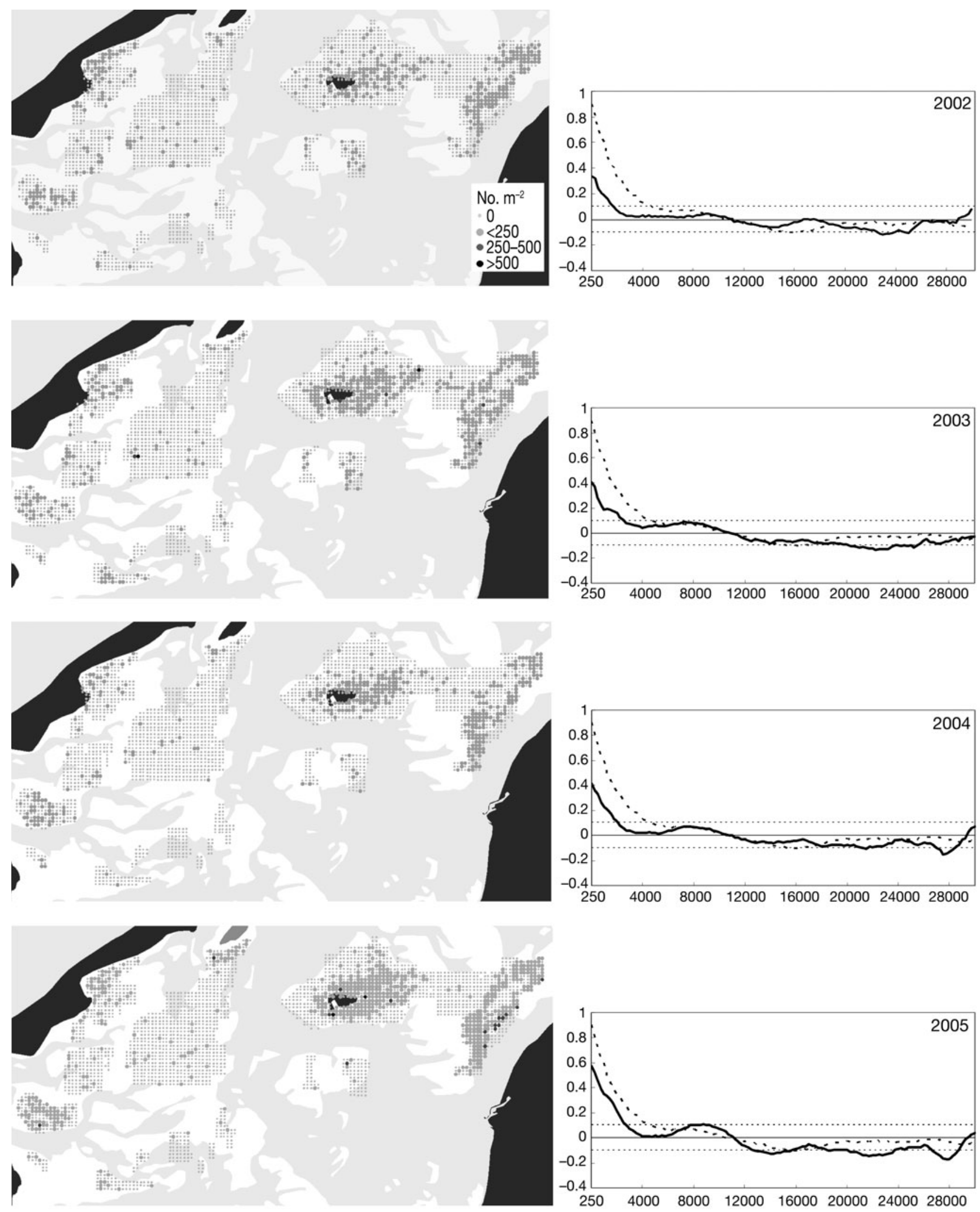

Fig. 4. Cerastoderma edule. Distribution from 2002 to 2005 (left panels) and the correlogram (solid line) of their spatial pattern; on the $x$-axis the distance (in $\mathrm{m}$ ) and on the $y$-axis Moran's $I$. The dotted, horizontal lines in the correlogram indicate the $95 \%$ CI.

The background autocorrelation, determined by the extent of intertidal flats, is represented by the dashed line 

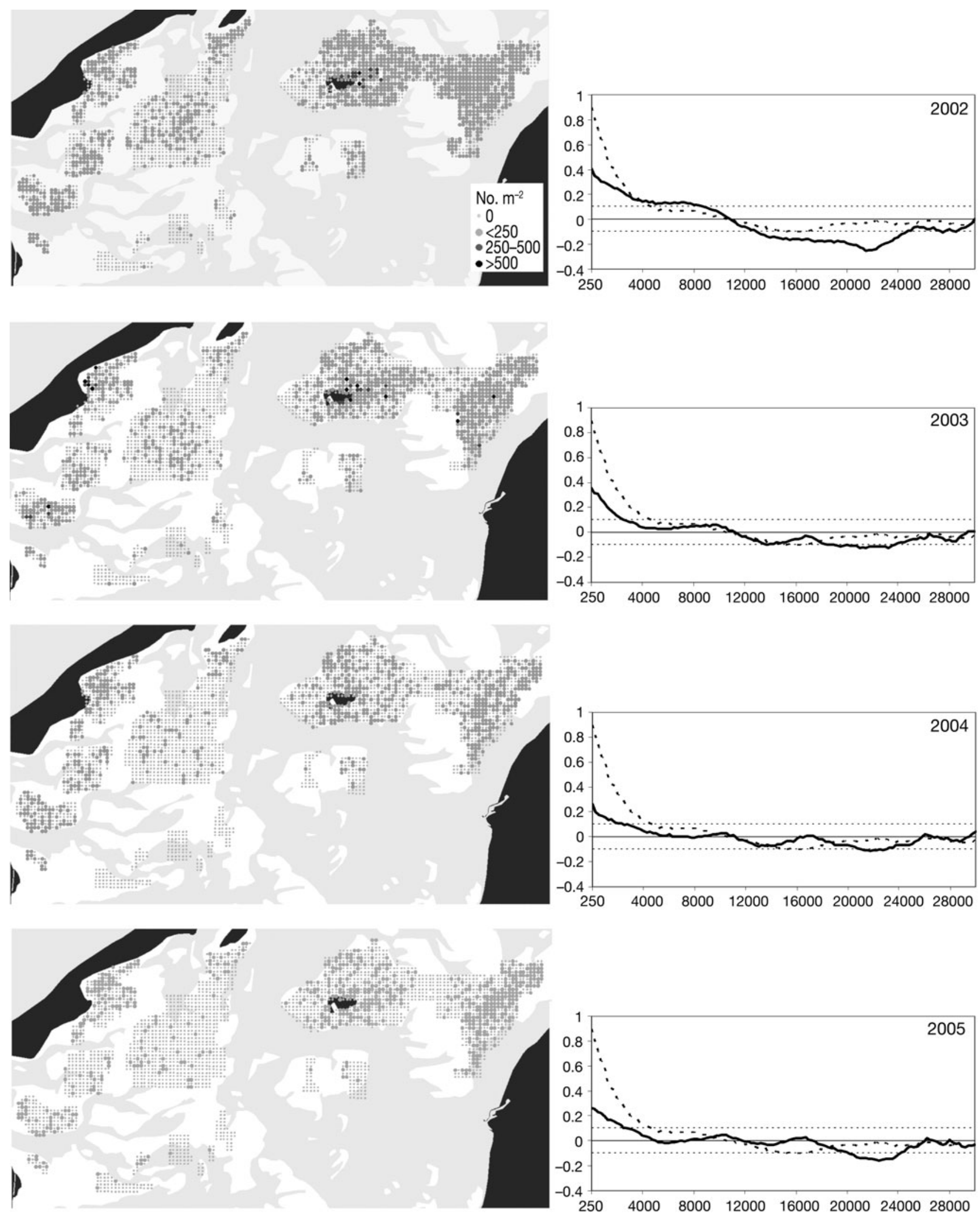

Fig. 5. Macoma balthica. Distribution from 2002 to 2005 (left panels) and the correlogram (solid line) of their spatial pattern; on the $x$-axis the distance (in $\mathrm{m}$ ) and on the $y$-axis Moran's I.. See Fig. 4 for further explanation 

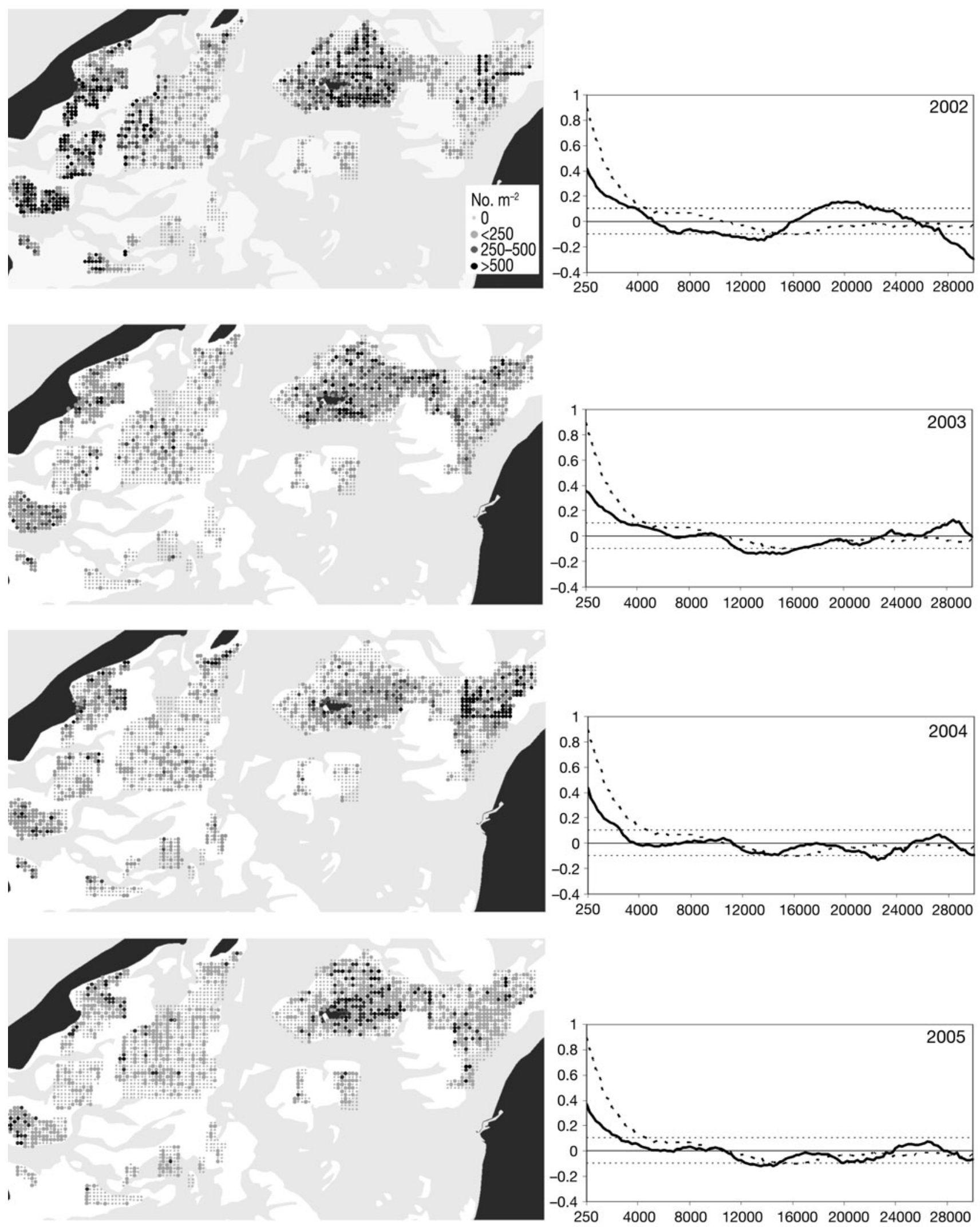

Fig. 6. Nereis diversicolor. Distribution from 2002 to 2005 (left panels) and the correlogram (solid line) of their spatial pattern; on the $x$-axis the distance (in $\mathrm{m}$ ) and on the $y$-axis Moran's I. See Fig. 4 for further explanation 

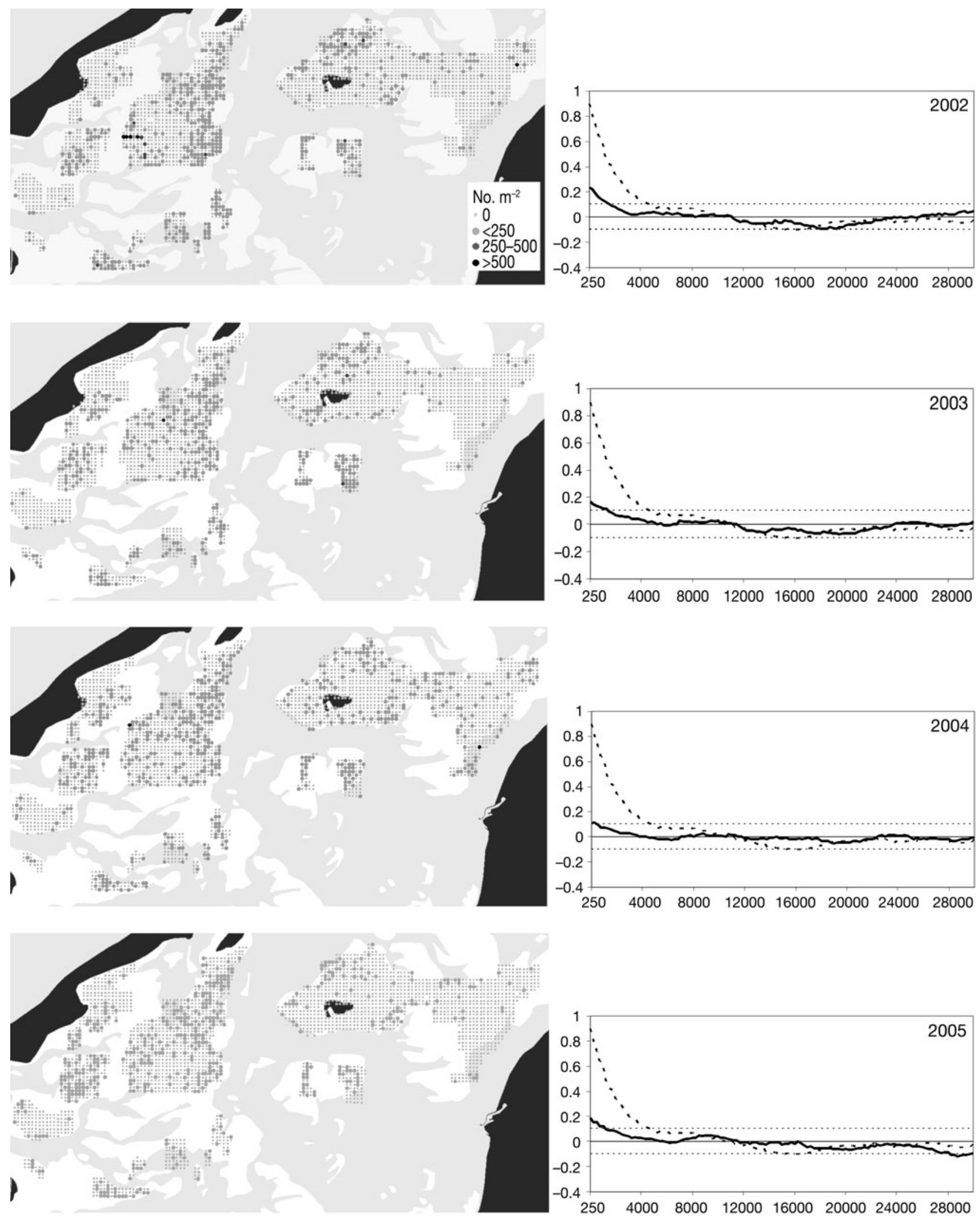

Fig. 7. Nepthys hombergii. Distribution from 2002 to 2005 (left panels) and the correlogram (solid line) of their spatial pattern; on the $x$-axis the distance (in $\mathrm{m}$ ) and on the $y$-axis Moran's I. See Fig. 4 for further explanation 
als and methods'). On average, the patch size of these intertidal habitats was $4000 \mathrm{~m}$.

The edible cockle Cerastoderma edule was distributed patchily across the intertidal areas (Fig. 4). Indeed, densities showed positive autocorrelations at the smallest distance-classes, followed by random oscillations around zero. In 2005, a year with higher than average densities due to spatfall, not only were the autocorrelations stronger than in other years (as shown by the higher value of Moran's I in the first distance class), but there was also a second peak at a distance of $9 \mathrm{~km}$ that indicated repetition of patches. Cockles more or less displayed the same distribution across the intertidal areas for all years, as shown by the distribution maps, with a gravitational centre of occurrence in the eastern part of the western Dutch Wadden Sea (Fig. 4). The maps show that the areas with the highest occurrence of cockles remained in place; only the density changed. In general, the spatial range or patch size was approximately $2000 \mathrm{~m}$.

Macoma balthica was undergoing a decline in the western Dutch Wadden Sea during the 4 study years (left panels, Fig. 5), something that is also reflected in the spatial structuring. With decreasing abundance and an increasingly homogeneous distribution, the amplitude of Moran's $I$ in the first distance class decreased between $2002(I=0.4)$ and 2005 ( $I=0.3)$ (Fig. 5), with patch sizes of $M$. balthica decreasing from $8000 \mathrm{~m}$ in 2002 to $3500 \mathrm{~m}$ in 2005, a value only marginally lower than the overall physical patch size (dashed line).

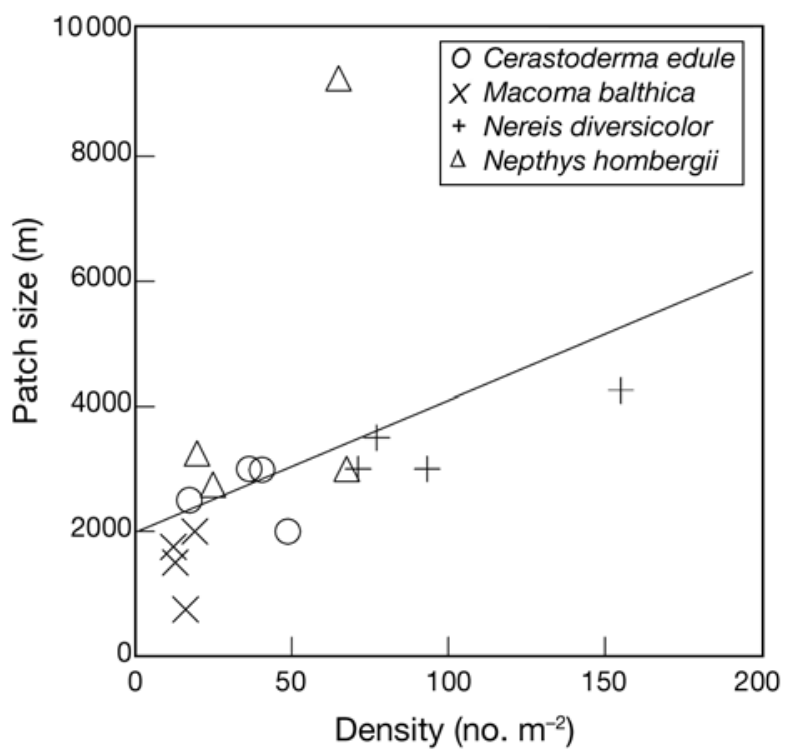

Fig. 8. Patch size in relation to the density of the 4 benthic species studied (Cerastoderma edule, Macoma balthica, Nereis diversicolor and Nepthys hombergii) from 2002 to 2005 (see Figs. 4-7)
Ragworms Nereis diversicolor, as shown by the maps, showed high densities and variation in their distribution across the western Dutch Wadden Sea between years (Fig. 6). In 2002 they were most common in the western part of our research area; in 2005 the highest densities were found in the middle and east of our sampling grid. The correlograms were quite similar throughout, with a spatial structure that ranged between 3000 and $4000 \mathrm{~m}$, although there was a second peak at $20 \mathrm{~km}$ in 2002 and not afterwards.

The predatory polychaete Nepthys hombergii generally occurred in low densities throughout our sampling area (Fig. 7), with the highest abundances in more sandy areas (pers. obs.). N. hombergii, besides short-distance autocorrelation, showed no other spatial structure. Especially in 2004, the distribution approached randomness.

\section{Overall comparison}

In general, the more striking spatial structures are shown by the most abundant species. Not only is patch size larger in these species (Fig. 8), they also reveal higher amplitudes in the correlograms (Figs. 4 to 7). An ANCOVA (Systat Software) confirmed that slope and intercept were not statistically different between species (slope, $F_{3,11}=2.052, \mathrm{p}=0.17$; intercept, $F_{1,11}=1.95$, $\mathrm{p}=0.19)$. Regression analysis showed a significant relationship between density and patch size $\left(F_{1,14}=\right.$ 9.531, $\left.\mathrm{p}<0.01, \mathrm{R}^{2}=0.44\right)$. This pattern was maintained when the threshold value for significance was varied (see 'Materials and methods'). Overall, the correlograms visually best resembled the simulated patterns of randomly distributed and differently sized patches (Fig. 3f) and multiple random small patches (Fig. 3e), both characterized by short-distance positive autocorrelation and noise at larger distances.

\section{DISCUSSION}

Although spatially explicit analytical methods are common practice in plant and landscape ecology (e.g. Sokal \& Oden 1978, Cliff \& Ord 1981), with notable exceptions (Thrush et al. 1989, Hewitt et al. 1997a,b, Legendre et al. 1997) they seem underexplored in marine science. The multitude of different techniques available (e.g. Fortin \& Dale 2005), ranging from Moran's $I$ to the Mantel statistic, can be daunting. We tested and compared 3 methods to determine spatial structuring on artificial data, i.e. Moran's I, semivariance and fractals.

Calculating the fractal dimension is informative when the variogram is linear (Fortin \& Dale 2005), 
which only occurs when species are distributed randomly or as gradients across the area under study. Analysis of the simulated spatial patterns showed that the presence of structure dismissed fractals as a relevant statistic. A posteriori our decision was validated by patterns encountered in the benthic data; gradients and random distributions were never encountered (Figs. 4 to 7). The 2 other methods were able to capture all computer-generated patterns. However, Moran's $I_{\text {, }}$ unlike semivariance, is standardized and all correlograms are therefore expressed on the same scale and allow direct comparison. Consequently, we choose Moran's $I$ as the most appropriate method to analyze spatial patterns of intertidal benthos.

The 4 macrobenthic species displayed spatial structuring at the scale of our benthic monitoring programme, i.e. the western Dutch Wadden Sea. This landscape-scale description of spatial patterns, as shown by the literature survey (Fig. 1, Table 1), is only rivalled by a limited number of studies, none of which were marine. The most obvious structures were smallscale patches, with a range of a few distance classes (Figs. 4 to 7), reaching a diameter of up to $9000 \mathrm{~m}$. These patterns, comparable to the simulated multiple random patches (Fig. 3f), persisted across the years, although some species (e.g. Nereis diversicolor) changed their distribution from west to east. The only noticeable change was the amplitude that increased with the occurrence of successful recruitment or decreased due to mortality and/or a more even distribution (Figs. 4 to 7). Apart from McArdle \& Blackwell (1989), also a marine study, the present study is the only one extending the analysis beyond a single snapshot in time, which allowed us to show the temporal constancy of spatial patterns.

Patterns also differed from the intrinsic autocorrelation imposed by the monitored points (reflecting the physical structure of the mudflats), showing that species distributions are shaped by processes other than the extent of mudflats. To the best of our knowledge this is the first attempt to disentangle species' spatial patterns from those of the physical extent of their environment. It is likely that a combination of factors such as sediment composition, inundation time, spatial variation in recruitment or interspecific interactions determines spatial patterning of benthic infauna (Thrush 1991, Legendre et al. 1997). This, however, still awaits verification within a framework that also explicitly takes the spatial variation of environmental parameters into account. Generalised Estimation Equations (GEE) seem to offer an elegant solution (Dormann et al. 2007).

Currently, in every study a sampling design is chosen, with a certain extent and grain that matches its questions or funding. However, patterns change with scale, and what appears a gradient on a large scale can be described as patchy on smaller scales (Levin 1992). Therefore, every study is reduced to a description of spatial pattern for a specific area with a specific sampling scheme. However, what unifies all studies is the occurrence of spatial heterogeneity in the distribution of their study organism ranging from a few meters to landscape-scale patterns (Table 1).

It is obvious that the ecological world is spatially structured (Sparrow 1999, Wiens 2000). Currently, 2 approaches exist to deal with this spatial variability. One focuses on the mathematical aspects of spatial structure (e.g. He et al. 2007), whereas another views autocorrelation as an ecological parameter (e.g. Kohler et al. 2006). It is this last approach which is the most rewarding, since it could potentially enhance the ecological understanding of, for example, benthossediment relationships in intertidal areas within a spatially explicit framework.

Acknowledgements. We were based on the Royal NIOZ RV 'Navicula' for the larger part of our research, and we thank Capt. K. van de Star, H. de Vries and J. Tuntelder for their help on-board and during sampling. Special thanks to crew member T. van der Vis for sampling efforts beyond the call of duty. We thank V. Natuurmonumenten for permission to work around the island of Griend and to use their warden's hut. A large number of volunteers and students contributed to the collection of the field data. C. Raaijmakers made a large contribution to the work in the laboratory. We thank H. Olff for ideas and encouragement, and E. O. Folmer, J. A. van Gils and R. Dapper for feedback and help with databases.

\section{LITERATURE CITED}

Bellehumeur C, Legendre P (1998) Multiscale sources of variation in ecological variables: modeling spatial dispersion, elaborating sampling designs. Landscape Ecol 13:15-25

Bergström U, Englund G, Bonsdorff E (2002) Small-scale spatial structure of Baltic Sea zoobenthos: inferring processes from patterns. J Exp Mar Biol Ecol 281:123-136

Beukema JJ, Essink K, Michaelis H, Zwarts L (1993) Year-toyear variability in the biomass of macrobenthic animals on tidal flats of the Wadden Sea: How predictable is this food source for birds? Neth J Sea Res 31:319-330

Burrough PA (1981) Fractal dimensions of landscapes and other environmental data. Nature 294:240-242

Carr MH, Neigel JE, Estes JA, Andelman S, Warner RR, Largier JL (2003) Comparing marine and terrestrial ecosystems: implications for the design of coastal marine reserves. Ecol Appl 13(Suppl.):90-107

Cliff AD, Ord JK (1981) Spatial processes: models and applications. Pion Limited, London

Cole RG, Syms C (1999) Using spatial pattern analysis to distinguish causes of mortality: an example from kelp in north-eastern New Zealand. J Ecol 87:963-972

Cole RG, Healy TR, Wood ML, Foster DM (2001) Statistical analysis of spatial pattern: a comparison of grid and hierarchical sampling approaches. Environ Mon Assess 69:85-99

Dankers N, Zuidema DR (1995) The role of the mussel (Mytilus edulis L.) and mussel culture in the Dutch Wadden Sea. Estuaries 18:71-80 
Dekker R, Beukema JJ (1999) Relations of summer and winter temperatures with dynamics and growth of two bivalves, Tellina tenuis and Abra tenuis, on the northern edge of their intertidal distribution. Neth J Sea Res 42:207-220

> Dormann CF, McPherson JM, Araújo MB, Bivand R and others (2007) Methods to account for spatial autocorrelation in the analysis of species distributional data: a review. Ecography 30:609-628

Elton CS (1966) The pattern of animal communities. Methuen \& Company, London

Fauchald P, Erikstad KE, Systad GH (2002) Seabirds and marine oil incidents: Is it possible to predict the spatial distribution of pelagic seabirds? J Appl Ecol 39:349-360

> Flach EC (1996) The influence of the cockle, Cerastoderma edule, on the macrozoobenthic community of tidal flats in the Wadden Sea. PSZN I: Mar Ecol 17:87-98

Fortin MJ (1999) Effects of sampling unit resolution on the estimation of the spatial autocorrelation. Ecoscience 6: 636-641

Fortin MJ, Dale M (2005) Spatial analysis: a guide for ecologists. Cambridge University Press, Cambridge

Fortin MJ, Drapeau P, Legendre P (1989) Spatial autocorrelation and sampling design. Vegetatio 83:209-222

He F, Legendre P, Bellehumeur C, LaFrankie JV (1994) Diversity pattern and spatial scale: a study of a tropical rain forest of Malaysia. Environ Ecol Stat 1:265-286

He Z, Zhao W, Chang X (2007) The modifiable areal unit problem of spatial heterogeneity of plant community in the transitional zone between oasis and desert using semivariance analysis. Landscape Ecol 22:95-104

Hewitt JE, Thrush SF, Cummings VJ, Pridmore RD (1996) Matching patterns with processes: predicting the effect of size and mobility on the spatial distributions of the bivalves Macomona liliana and Austrovenus stutchburyi. Mar Ecol Prog Ser 135:57-67

Hewitt JE, Legendre P, McArdle BH, Thrush SF, Bellehumeur C, Lawrie SM (1997a) Identifying relationships between adult and juvenile bivalves at different spatial scales. J Exp Mar Biol Ecol 216:77-98

Hewitt JE, Pridmore RD, Thrush SF, Cummings VJ (1997b) Assessing the short-term stability of spatial patterns of macrobenthos in a dynamic estuarine system. Limnol Oceanogr 42:282-288

Hewitt JE, Thrush SF, Cummings VJ, Turner SJ (1998) The effect of changing sampling scales on our ability to detect effects of large-scale processes on communities. J Exp Mar Biol Ecol 227:251-264

Huxam M, Richards M (2003) Can postlarval bivalves select sediment type during settlement? A field test with Macoma balthica (L.) and Cerastoderma edule (L.). J Exp Mar Biol Ecol 288:279-293

Johnson GD, Tempelman A, Patil GP (1995) Fractal based methods in ecology: a review for analysis at multiple spatial scales. Coenoses 10:123-131

Jumars PA, Thistle D, Jones ML (1977) Detecting two-dimensional spatial structure in biological data. Oecologia 28: 109-123

Klaassen RHG, Nolet BA, Bankert D (2006) Movement of foraging tundra swans explained by spatial pattern in cryptic food densities. Ecology 87:2244-2254

Kohler F, Gillet F, Reust S, Wagner HH, Gadallah F, Gobat JM, Buttler A (2006) Spatial and seasonal patterns of cattle habitat use in a mountain wooded pasture. Landscape Ecol 21:281-295

Kraan C, Piersma T, Dekinga A, Koolhaas A, van der Meer J (2007) Dredging for edible cockles Cerastoderma edule on intertidal flats: short-term consequences of fishermen's patch-choice decisions for target and non-target benthic fauna. ICES J Mar Sci 64:1735-1742

Legendre P, Fortin MJ (1989) Spatial patterns and ecological analysis. Vegetatio 80:107-138

Legendre P, Legendre L (1998) Numerical ecology. Elsevier, Amsterdam

> Legendre P, Thrush SF, Dayton PK, Grant J and others (1997) Spatial structure of bivalves in a sandflat: scale and generating processes. J Exp Mar Biol Ecol 216:99-128

Levin SA (1992) The problem of pattern and scale in ecology. Ecology 73:1943-1967

Maestre FT, Rodríguez F, Bautista S, Cortina J, Bellot J (2005) Spatial associations and patterns of perennial vegetation in a semi-arid steppe: a multivariate geostatistics approach. Plant Ecol 179:133-147

Manly BFJ (1997) Randomization, bootstrap and Monte Carlo methods in biology. Chapmann \& Hall, London

McArdle BH, Blackwell RG (1989) Measurement of density variability in the bivalve Chione stutchburyi using spatial autocorrelation. Mar Ecol Prog Ser 52:245-252

$>$ Moran PAP (1950) Notes on continuous stochastic phenomena. Biometrika 37:17-23

> Morrisey DJ, Howitt L, Underwood AJ, Stark JS (1992) Spatial variation in soft-sediment benthos. Mar Ecol Prog Ser 81: 197-204

Palmer MW (1988) Fractal geometry: a tool for describing spatial patterns of plant communities. Vegetatio 75:91-102

Perry JN, Liebhold AM, Rosenberg MS, Dungan J, Miriti M, Jakomulska A, Citron-Pousty S (2002) Illustrations and guidelines for selecting statistical methods for quantifying spatial pattern in ecological data. Ecography 25:578-600

Peterson CH (1991) Intertidal zonation of marine invertebrates in sand and mud. Am Sci 79:236-249

Pinckney J, Sandulli R (1990) Spatial autocorrelation analysis of meiofaunal and microalgal populations on an intertidal sandflat: scale linkage between consumers and resources Estuar Coast Shelf Sci 30:341-353

Piersma T, Hoekstra R, Dekinga A, Koolhaas A, Wolf P, Battley P, Wiersma P (1993) Scale and intensity of intertidal habitat use by knots Calidris canutus in the western wadden sea in relation to food, friends and foes. Neth J Sea Res 31:331-357

> Piersma T, Koolhaas A, Dekinga A, Beukema JJ, Dekker R, Essink K (2001) Long-term indirect effects of mechanical cockle-dredging on intertidal bivalve stocks in the Wadden Sea. J Appl Ecol 38:976-990

> Rangel TFLVB, Diniz-Filho JAF, Bini LM (2006) Towards an integrated computational tool for spatial analysis in macroecology and biogeography. Glob Ecol Biogeogr 15: 321-327

Real LA, McElhany P (1996) Spatial pattern and process in plant - pathogen interactions. Ecology 77:1011-1025

Reiné R, Chocarro C, Fillat F (2006) Spatial patterns in seed bank and vegetation of semi-natural mountain meadows. Plant Ecol 186:151-160

Reise K (1979) Spatial configurations generated by mobile benthic polychaetes. Helgol Mar Res 32:55-72

Robertson GP (2000) Geostatistics for the environmental sciences. Gamma Design Software, Plainwell, MI, available at www.gammadesign.com

Rossi RE, Mulla DJ, Franz EH (1992) Geostatistical tools for modeling and interpreting ecological dependence. Ecol Monogr 62:277-314

Sandulli R, Pinckney J (1999) Patch sizes and spatial patterns of meiobenthic copepods and benthic microalgae in sandy sediments: a microscale approach. Neth J Sea Res 41: 179-187 
Segurado P, Araújo MB, Kunin WE (2006) Consequences of spatial autocorrelation for niche-based models. J Appl Ecol 43:433-444

Sokal RR, Oden NL (1978) Spatial autocorrelation in biology. 1. Methodology. Biol J Linn Soc 10:199-228

Sparrow AD (1999) A heterogeneity of heterogeneities. Trends Ecol Evol 14:422-423

Stewart AJA, John EA, Hutchings MJ (2000) The world is heterogeneous: ecological consequences of living in a patchy environment. In: Hutchings MJ, Stewart AJA (eds) The ecological consequences of environmental heterogeneity. Blackwell Science, Oxford, p 1-8

Thomson JD, Weiblen G, Thomson BA, Alfaro S, Legendre P (1996) Untangling multiple factors in spatial distributions: lilies, gophers, and rocks. Ecology 77:1698-1715

$>$ Thrush SF (1991) Spatial patterns in soft-bottom communities. Trends Ecol Evol 6:75-79

- Thrush SF, Hewitt JE, Pridmore RD (1989) Patterns in the spatial arrangements of polychaetes and bivalves on intertidal sandflats. Mar Biol 102:529-535

Thrush SF, Pridmore RD, Hewitt JE (1994) Impacts on softsediment macrofauna: the effects of spatial variation on temporal trends. Ecol Appl 4:31-41

van der Meer J (1997) Sampling design of monitoring programmes for marine benthos: a comparison between the use of fixed versus randomly selected stations. Neth J Sea Res 37:167-179

van der Meer J, Leopold MF (1995) Assessing the population size of the European storm petrel (Hydrobates pelagicus) using spatial autocorrelation between counts from segments of criss-cross ship transects. ICES J Mar Sci 52: 809-818

van Gils JA, Piersma T, Dekinga A, Spaans B, Kraan C (2006a) Shellfish-dredging pushes a flexible avian top predator out of a protected marine ecosystem. PLoS Biol 4:e376

Editorial responsibility: Romuald Lipcius, Gloucester Point, Virginia, USA van Gils JA, Spaans B, Dekinga A, Piersma T (2006b) Foraging in a tidally structured environment by red Knots (Calidris canutus): ideal, but not free. Ecology 87: 1189-1202

van Rensburg BJ, Chown, SL, Gaston KJ (2002) Species richness, environmental correlates, and spatial scale: a test using South African birds. Am Nat 159:566-577

Verwey J (1952) On the ecology of distributions of cockle and mussel in the Dutch Waddensea, their role in sedimentation and the source of their food supply. Arch Neerl Zool:171-239

- Volckaert F (1987) Spatial pattern of soft-bottom Polychaeta off Nova Scotia, Canada. Mar Biol 93:627-639

- Watling L, Norse EA (1998) Disturbance of the seabed by mobile fishing gear: a comparison to forest clearcutting. Conserv Biol 12:1180-1197

Wiens JA (2000) Ecological heterogeneity: an ontogeny of concepts and approaches. In: Hutchings MJ, John EA, Stewart AJA (eds) The ecological consequences of environmental heterogeneity. Blackwell Science, Oxford, p 9-31

Wu J, Hobbs R (2002) Key issues and research priorities in landscape ecology: an idiosyncratic synthesis. Landscape Ecol 17:355-365

Zar JH (1996) Biostatistical analysis. Prentice Hall, Upper Saddle, NJ

Zwarts L, Wanink JH (1993) How the food supply harvestable by waders in the wadden sea depends on the variation in energy density, body weight, biomass, burrying depth and behaviour of tidal-flat invertebrates. Neth J Sea Res 31: 441-476

Zwarts L, Dubbeldam W, van den Heuvel H, van de Laar E, Menke U, Hazelhoff L, Smit CJ (2003) Bodemgesteldheid en mechanische kokkelvisserij in de Waddenzee. RIZA, Lelystad

Submitted: January 23, 2008; Accepted: February 3, 2009

Proofs received from author(s): April 30, 2009 